\author{
cumhuriget ilahigat dergisi 20, sy. 1 (Haziran 2016): 225-244 \\ cumhuriget theology journal 20, no. 1 (June 2016): 225-244 \\ \& Hakemli Araşturma Makalesi / Peer-reviewed Research Article os
}

\title{
Engelli Çocuğa Sahip Annelerde Yas Süreci
}

Grief Process of Mothers of Children with Intellectual Disabilities

Ayşe Burcu GÖREN *

Öz

Kayıp ve yas deneyimi, yaşamın doğal bir parçasıdır. Her insan hayatının farklı dönemlerinde çok çeşitli kayıplar yaşar ve bu kayıplar için yas tutar. Bu anlamda kayıp ve yas evrenseldir. Yas bir iyileşme sürecidir. Yas denildiğinde akla ilk gelen ölüm olmakla beraber, aslında kişi için anlamlı olan herşeyin kaybı yasa sebep olur. Yaşanan yas tepkilerinin şekli süresi ve boyutu, kaybın türüne, kaybın birey için anlamına ve yaşamındaki yerine, kültüre, inanca, kaybın gerçekleşme biçimine göre

\begin{abstract}
Loss is an inevitable part of life and grief is a natural part of the healing process. In this sense, the grieving process is universal. People commonly associate certain losses with strong feelings of grief. Although the concept of grief is a direct reminder of death, grief and loss can happen in different ways - death, divorce, deployment or other situations of abandonment. Different effects can influence how people understand and approach the grief process such as importance and place of the loss in life, cultural background, belief systems, etc. Having mentally retarded child is also
\end{abstract}

\footnotetext{
* Yrd. Doç. Dr., Turgut Özal Üniversitesi Sağlik Yüksekokulu, Sosyal Hizmet Bölümü. Assistant Professor, University of Turgut Özal, Department of Social Work. Ankara/Turkey (abgoren@turgutozal.edu.tr).

- cumhuriget ilahigat dergisi'nde yayımlanan makaleler, en az iki hakem tarafından çift taraflı kör hakemlik değerlendirmesine tabi tutulur. Ayrıca intihal içermediği özel bir yazllım kullanılarak kontrol edilir.

\section{- cumhuriget theology journal uses doub-} le-blind review fulfilled by at least two reviewers. In addition, all articles are checked by means of a program in order to confirm they are not published before and avoid plagiarism.
} 
değişkenlik göstermektedir. Kayıp sonrasında yas sürecinin ertelenmeyerek yaşanması gerekir. Sağlıklı bir çocuk bekleyen annebabalar için zihinsel engelli bir çocuğa sahip olduğunu öğrenmek de, aynı şekilde ebeveyni bir yas sürecine sokmaktadır. Bu makalede, doğumla beraber zihinsel engelli bir çocuğa sahip olduğunu öğrenen annelerin yas tepkileri ve geçirdikleri yas aşamaları KüblerRoss'un aşama modeli bağlamında değerlendirilmiştir. Sonuç olarak annelerin bu süreçte tipik yas tepkileri vererek, yas aşamalarından geçtikleri belirlenmiştir. Ayrıca engelli çocuğa sahip annelerin yas sürecini sağlıklı atlatabilmek için yas danışmanlığı içeren psikolojik desteğe ihtiyaç duyabileceği görülmüştür.

ANAHTAR KELIMELER: Yas, Kayıp, Engellilik, Zihinsel engellilik, Engelli annesi. a shocking and unexpected situation for parents who are dreaming about a healthy baby. Parents can experience grief at this process. In 1969, psychiatrist Elisabeth Kübler-Ross introduced what became known as the "five stages of grief." These stages of grief were based on her studies of the feelings of patients facing terminal illness, but many people have generalized them to other types of negative life changes and losses, such as the death of a loved one, losses of dreams or unexpected disability situations. In this article, grief reactions of mothers who learns that she has a mentally retarded child during birth was investigated. It was determined that the five stages of grief proposed by Elisabeth KüblerRoss (denial, anger, bargaining, depression and acceptance) are experienced by mothers. Also it was observed that, mothers need grief counseling in this process.

KEYWORDS: Grief, Loss, Disability, Intellectual disability, Mother of disabled child.

\section{SUMMARY}

Loss is an inevitable part of life and grief is a natural part of the healing process. In this sense, the grieving process is universal. People commonly associate certain losses with strong feelings of grief. Although the concept of grief is a direct reminder of death, grief and loss can happen in different ways - death, divorce, deployment or other situations of abandonment. Different effects can influence how people understand and approach the grief process such as importance and place of the loss in life, cultural background, belief systems, etc. Having a disabled child is also a shocking and unexpected situation for parents who are dreaming

$$
\text { cumhuriget ilahigat dergisi 20, sy. 1 (Haziran 2016): 225-244. }
$$


about a healthy baby. Parents can experience grief at this process. Recent research has indicated that parents of children with special needs may experience feelings and symptoms of traumatic stress, particularly at the time of their child's diagnosis. Letting go of the hopes and dreams they originally had, and which no longer serve them, is an exceptionally complicated and complex process. These feelings of grief and loss are often experienced but rarely spoken about or shared. In 1969, psychiatrist Elisabeth Kübler-Ross introduced what became known as the "five stages of grief." These stages of grief were based on her studies of the feelings of patients facing terminal illness, but many people have generalized them to other types of negative life changes and losses, such as the death of a loved one, losses of dreams or unexpected disability situations.

Unexpected life events can have traumatic effects on the routine of life. It is important to determine the stages of grief reactions for the adoption of the correct approaches. For this purpose, in this article, grief reactions of mothers who learns that she has a mentally retarded child during birth was investigated. Therefore, semi-structured and open ended interviews were conducted with twenty mothers with disabled child, living in Ankara. Systematic analysis of data reveal that mothers with disabled child experiencing grief reactions. It was determined that the five stages of grief proposed by Elisabeth Kübler-Ross (denial, anger, bargaining, depression and acceptance) are experienced by mothers. Those stages are not a linear and predictable progression but generally mothers reported that they firstly feel shocked and denial. At this stage, mothers believe the diagnosis is somehow mistaken or it was a nightmare that will end soon. When mothers recognize that denial cannot continue, they become frustrated, Anger stage is characterized by those sentences: Why me? It's not fair!"; "How can this happen to me?"; "'Who is to blame?"; "Why would this happen?". Bargaining is the third stage. The third stage involves the hope that the mother can avoid a cause of grief. Mothers seek for rational or irrational remedies with the hope of changing the result. Depression is the stage which involves the mothers experiencing sadness when they know there is nothing else to be done, and they realize they cannot change the disability. Sadness and hopelessness are important parts of the depression stage. In this state, mother feel herself really alone in life, may become silent, refuse attending social activities and spend

$$
\text { cumhuriget theology journal 20, no. I (June 2016): 225-244. }
$$


much of the time mournful. The last stage of grief is acceptance. This does not necessarily mean that mother will be completely happy again. In this last stage, mothers accept the reality of disability. "Let us see in front of us, if this is the situation, what can I do best for me and my child?" Every parent is different, and grief is a uniquely individual process. There is no "right" or "wrong" way to experience grief; however, mothers need to have the space to fully experience and express all of these important feelings. So it was observed that, mothers need grief counseling in this process. Mothers of children with disabilities are in need of support and care at every stage. This requirement includes those steps:

1. Mothers often need help in understanding their child's disability. Especially at the first explaining the reality of disability, providing professional health care with a humanitarian approach is extremely effective on the mother's grief reactions.

2. Mother of a disabled child needs support from family members. Family members should be educated about the grieving process and need for support of mother.

3. For a healthy grieving, mothers need psychological counseling support to overcome the loss by professional grief counselors at this process. A professional grief counseling system is a necessity for the mothers of disabled children.

\section{GİRIŞ}

Kayıp yaşayan bireyin kayba verdiği tepkiye, genel anlamda yas denir. Yas ya da diğer adıyla matem, evrensel bir süreç olmakla beraber, bireyin kişilik yapısı, içinde yaşadığı toplumun özellikleri ve kültüre göre yasın yaşanış biçimi değişebilmektedir. ${ }^{1}$ Yas sürecinde birey, yaşanan kaybın yol açtı̆̆ olumsuz duygu ve düşünceler içindedir ve buna bağlı olarak alışılagelmiş yaşamından farklı davranışlarda bulunabilir. ${ }^{2}$ Kayba

1 J.William Worden, Grief Counseling And Grief Therapy: A Handbook For The Mental Health Practitioner (Springer Publishing Company, 2009), 57-83.

2 Ayten Zara, Kayıplar, Yas Tepkileri ve Yas Süreci,Yaşadıkça: Psikolojik Sorunlar ve Başa Çıkma Yolları, (Edt) (İstanbul: İmge Yayınları, 2011), 73-90.

$$
\text { cumhuriget ilahigat dergisi 20, sy. 1 (Haziran 2016): 225-244. }
$$


verilen yas tepkilerinin, sosyal yaşamdan uzaklaşma, iş performansının düşüşü, yeme içme gibi temel ihtiyaçlarının karşılanmasını ihmal gibi yansımaları olabilir ${ }^{3}$. Yas süreci, kaybın niteliği, kaybın bireyin yaşamındaki yeri ve anlamı, kişilik özellikleri ve yas sürecinde alınan sosyal destek gibi pek çok faktöre bağlı olarak şekillenmektedir' ${ }^{4}$. Yas süreci, bu faktörlerin yanısıra, elbette her bireyin biricik olması nedeniyle kişiye has bir süreç olarak yaşanmaktadır. Bununla beraber, kayba verilen tepkilerin benzerlik gösterdiği birtakım yönlerini belirlemek de mümkündür. Kayba verilen tepkiler fiziksel, duygusal, bilişsel ve davranışsal boyutta çeşitlilik gösterebileceği gibi, ${ }^{5}$ yası tutulan kayıp da başta ölüm olmak üzere çeşitlilik göstermektedir. ${ }^{6}$ Çünkü her ne kadar yas ve kayıp kavramları ölümü akla getirse de, yas tutma yada matem, genel olarak, "anlamlı öteki"nin kaybı olarak tanımlanmaktadır.7 Her türü ile kayıp ve yas, istisnasız her insanın yaşamının bir döneminde bir şekilde deneyimlediği bir tecrübedir. Ölüm, kayıp türleri arasında en somut, en bilindik olanı olmakla beraber, kayıp denince akla, daha kapsamlı olarak, sağlığın kaybı, organ kaybı, makam kaybı, bir dostun, sevilenin kaybı, boşanma ve ayrılıklar, umutlarımızı ya da hatıralarımızı sembolize eden herhangi bir objenin kaybı gibi çok çeşitli kayıp yaşantıları gelmelidir. ${ }^{8}$ Yas kavramının ölüm sonrası yaşanan süreçle sınırlandırılmadığını belirlemek önemlidir. Sağlığın kaybı, geleceğe dair hayallerin kaybı, bir kaza ya da savaş neticesinde bir organın kaybı gibi kayıpların her biri yas süreci gerektirmektedir. Aynı şekilde, sağlıklı bir çocuk beklerken, engelli bir çocuğa sahip olduğunu öğrenmek de, benzer bir yas süreci gerektirir ve benzer yas tepkilerinin yaşanmasına sebep olabilir. Aileler için engelli

3 Elif Kara, "Yas Süreci ve Dini Danışmanlık", Dokuz Eylül Üniversitesi İlahiyat Fakültesi Dergisi Din Psikolojisi Özel Sayısı (2016), 251-270.

4 Cem Ali Gizir, "Bir Kayıp Sonrasında Zorluklar Yaşayan Üniversite Öğrencilerine Yönelik Bir Yas Danışmanlığı Modeli”, Mersin Üniversitesi Ĕ̆itim Fakültesi Dergisi 2, 2 (2006), 195-213.

5 Ayşe Özlem Mestçioğlu ve Ebru Sorgun, Travmatik Yas. İçinde Aker T. ve Önder M.E. (Edt), Psikolojik Travma ve Sonuçları (İstanbul: 5US Yayınları, Epsilon Reklamcılık, 2003), 179-193.

6 Özlem Işıl ve Semra Karaca, "Ölüm Yaklaşırken Yaşananlar Ve Söylenebilecekler: Bir Gözden Geçirme", Maltepe Üniversitesi Hemşirelik Bilim ve Sanatı Dergisi 1, 8 (2009), 2-7.

Erol Göka, Hoşçakal (İstanbul: Timaş Yayınları, 2009), 149.

8 Karen M. Humphrey, Counseling Strategies For Loss And Grief (Alexandria, VA: American Counseling Association, 2009)

$$
\text { cumhuriget theology journal 20, no. 1 (June 2016): 225-244. }
$$


bir çocuğa sahip olacaklarını ya da olduklarını öğrenmek, yaşamlarının en zor tecrübesidir. Engelli çocuğa sahip olmak, anne baba için pek çok yönüyle zorlu ve üzücüdür. Aileye katılması beklenen çocuk, aile olma mutluluğunun tamamlayıcı bir parçası, aileyi kuran bireylerin "en önemli eseri" ve "ailenin en değerli ürünü" olarak görülür. Her anne-baba adayının, geçmişten bu yana, çocuk sahibi olmakla ilgili, sahip olacakları çocuğun dış görünüşü, yetenekleri, başarılarıyla ilgili birikmiş hayalleri olur. Bu hayaller, gebelik sürecinde beslenir, bebekle beraber vücut bulur, büyür, gelişir ve doğum bu anlamıyla, hayata yeni başlayan bir bireyin omzuna çok büyük hayal ve beklentiler yükler. Yenidoğanda anne-babanın izlerinden işaretler aranması belki de bu yüzdendir. Aile bireyleri için çocuk, bir gelecek garantisi, kadın ve erkek için tam ve sağlıklı oluşun bir kanıtı, kadın ve erkeğin ortak ürünü, eseri olarak görülmektedir. ${ }^{9}$ Bu eserdeki payını görmek ve bununla beslenmek, anne baba için- hiç dile getirilmese de- en önemli doyum kaynaklarından biri olur. Ancak hayallerle süslenen bebeği karşılama anında bazı anne babalar, hiç beklemedikleri, hayallerinde yeri olmayan ve asla istemeyecekleri bir sürprizle karşılaşırlar. Bu beklenmedik durum anne baba için oldukça şok edici olmaktadır. ${ }^{10}$ Yalom'a göre çocuk, kişinin yaşam projesinin ta kendisidir - ne için yaşadığı, gelecekte kendini nasıl tasarladığı, ölümü aşmayı nasıl umut edebileceğidir yani insanın çocuğu aslında onun ölümsüzlük projesidir.11 Aileler, kendi eserleri -projeleri olarak gördükleri bir çocuk idealize ederler. Ailelerin yaşadıkları bu psikolojik sürecin önemli bir nedeni de, idealize ettikleri çocuk beklentisidir. Engelli bir çocuğa sahip olmanın aile yaşamında yaptı̆̆ 1 çeşitli etkilere dair anne babalarla yapılmış birçok araştırma sonucu mevcuttur. ${ }^{12}$ Engelli çocuğa sahip ailelerin, belirgin yas tepkileri gösterdikleri bilinmektedir. ${ }^{13}$ Anne- baba, gerçeğin kabullenilmesine kadar geçen yas sürecinde bir dizi

9 Robert M. Smith ve John T. Neisworth, The Exceptional Child: A Functional Approach (New York: McGraw-Hill,1975)

10 A. Burcu Gören, "Down Sendromlu Bireylerin Manevi Bakım İhtiyactnın Belirlenmesi ve Bir Model Önerisi" (Doktora Tezi, Ankara Üniversitesi, 2015)

11 Irvin D. Yalom, Aşkın Celladı ve Diğer Psikoterapi Öyküleri (İstanbul:Remzi Kitabevi, 2000)

12 Mark Whiting, “What It Means To Be The Parent Of a Child With a Disability or Complex Health Need", Nursing Children and Young People 26, 5 (2014), 26-29.

13 Ken Moses, The Impact of Childhood Disability: The Parent's Struggle (WAYS Magazine, Spring. Evanston, IL, 1987).

$$
\text { cumhuriget ilahigat dergisi 20, sy. 1 (Haziran 2016): 225-244. }
$$


tepkilerden oluşan aşamalardan geçmektedir. ${ }^{14}$ Kübler-Ross, kayıp yaşayan bireylerin yas sürecini, inkar, öfke, pazarlık, depresyon, kabullenme olarak sıralamaktadır. ${ }^{15}$ Kayba verilen tepkilerin, yeni duruma uyum sağlamaya kadar aşamalar halinde ilerlediği belirleyen Ross'a göre yas sürecinin içerdiği beş temel aşama şu şekildedir:

1) İnkar: Kişinin, kaybı kabul etmediği, bir hata olmalı, benim başıma gelmiş olamaz gibi tepkiler verdiği dönemdir. Bu ilk aşama, şok edici duruma alışabilmek için organizmanın verdiği bir koruyucu tepki olarak bireye zaman kazandırması açısından yararlıdır.

2) Öfke: kaybın gerçekliği ile yüzleşilmesinin ardından, durumun sorumlusunun arandığı, nedenlerinin merak edildiği ve sorgulandığ 1 aşamadır. Engelli ailelerinde bu aşama, uzmanları suçlama, kendini suçlama, kaderi, Tanrıyı suçlama ve aile bireylerini suçlama şeklinde dört ayrı tarzda olmaktadır.

3) Pazarlık: Kişinin çaresizlik yalnızlık ve ümitsizlik içinde mucizevi iyileşmeler ümit ettiği ve bu gerçeği değiştirmek istediği evredir.

4)Depresyon: kişinin gerçeği tamamen idrak etmesiyle çaresizliğini kabullendiği ve acının gerçek anlamda yaşandığı dönemdir.

5)Kabullenme: gerçeğin kabulüyle birlikte, bundan sonra ne yapabiliriz sorusunun sorulduğu, yeni şartlara uyum sağlanarak hayatın yeniden organize edildiği evredir. ${ }^{16}$ Bundan 40 yıl önce Kübler-Ross, Ölüm ve Ölmek Üzerine adlı kitabında yer alan beş aşamalı modelini ölüm üzerinde çalışmış olsa da, günümüzde artık sadece ölüm karşısındaki tutum için değil, hayatta başa gelen önemli her tür değişiklik için uygulanmaktadır.

Yapılan çalışmalarda, engelli bir çocuğa sahip olan anne-babaların yeni şartlara uyumunda, aile yapısında, birbirleriyle ilişkilerinde ve iç

14 Nilüfer Darıca, Ülkü Abidinoğlu ve Şebnem Gümüşçü, Otizm ve Otistik Çocuklar (İstanbul: Özgür Yayınlan, 2000)

15 Elisabeth Kübler-Ross, Ölüm ve Ölmek Üzerine (İstanbul: Boyner Holding Yayınlar1,1997), 61-186.

16 Özge Genlik, "Yas Süreci ve Yas Sürecindeki Kişilerin Depresyon ve Anksiyete Düzeylerinin Incelenmesi" (Yüksek Lisans Tezi, Arel Üniversitesi, 2012), 24. cumhuriget theology journal 20, no. 1 (June 2016): 225-244. 
dünyalarında zorlanmalar ve değişimler yaşadıklarına ${ }^{17}$ yaşama bakış ve değerlendiriş tarzlarında bir takım etkilerin meydana gelebildiğine ${ }^{18}$ dair sonuçlara varılmıştır.

Yas sürecinde engelli çocuğun varlığıyla beraber aile şok ve inkar, acı ve depresyon, suçluluk, kararsızlık, öfke ve kızgınlık, utanma, pazarlık, kapı kapı dolaşma, mucize arama, uzlaşma, mantığa bürüme, uyum sağlama, kabul etme gibi gibi aşamalardan geçmektedir. Her annebaba her aşamayı yaşamayabileceği gibi, her aşamayı aynı uzunluk ve derinlikte deneyimlemeleri beklenmez. ${ }^{19}$

\section{ARAŞTIRMANIN AMACI VE ÖNEMI}

$\mathrm{Bu}$ araştırmada, doğumla beraber zihinsel engelli bir çocuğa sahip olduklarını öğrenen annelerin yaşadıkları yas sürecinin niteliklerini araştırmak amaçlanmıştır. Beklenmedik yaşam olayları hayatın rutin akışı üzerinde sarsıcı bir etki yapabilir. Bireylerin bu süreçte geçirdiği aşamaların belirlenmesi, doğru yaklaşım tarzlarının benimsenmesi açısından önem taşımaktadır.

\section{Evren ve Örneklem}

Araştırmanın evreni çocuğunun zihinsel engelli olduğunu doğumdan sonra öğrenen Ankara ilinde yaşayan annelerdir. Araştırmanın örneklemini ise araştırmacının kartopu yöntemiyle ulaştığ 20 zihinsel engelli çocuk annesi oluşturmaktadır.

\section{Veri Toplama Süreci}

Zihinsel engelli çocuğa sahip annelerle yarı yapılandırılmış açık uçlu mülakat yöntemi ile görüşmeler gerçekleştirilmiştir. Görüşmelere katılan anneler, Ankara ilinde, araştırmacının kişisel ilişkileri ile ulaştı̆̆ 1

17 Celalettin İçmeli, Ahmet Ataoğlu, Fatih Canan ve Adnan Özçetin, "Zihinsel Özürlü Çocukları Olan Ebeveynler Ile Sağlıklı Çocuklara Sahip Ebeveynlerin Çocuk Yetiştirme Tutumlarının Karşılaştırılması", Düzce Tip Fakültesi Dergisi, 3 (2008), 21-28.

18 Şükrü Uğuz, Fevziye Toros, Banu Yazgan İnanç ve Oğuzhan Çolakkadığlu, “ Zihinsel Ve/Veya Bedensel Engelli Çocukların Annelerinin Anksiyete, Depresyon ve Stres Düzeylerinin Belirlenmesi", Klinik Psikiyatri, 7 (2004), 42-47.

19 Nihal Varol, Aile Ĕ̆itimi (Ankara: Kök Yayıncılık, 2005), 22-45.

$$
\text { cumhuriget ilahigat dergisi 20, sy. 1 (Haziran 2016): 225-244. }
$$


kişiler arasından araştırmaya katkıda bulunmaya gönüllü olan kişilerden oluşmuştur. Görüşmeler öncesinde araştırmacl, konunun annelerin yaşamındaki etkisi ve anlamını göz önünde bulundurarak, tanışma ve muhatabını rahatlatmaya özen göstermiştir. Araştırmacının Down Sendromlu bir kardeşe sahip olması, bu noktada vurgulanmaya değerdir, çünkü görüşülen anneler, görüşmenin özellikle ilk safhasında kendileri için paylaşması zor olan bu konuyu kendileri ile benzer yaşamsal tecrübelerden geçmiş biri ile paylaşmaktan memnun olduklarını dile getirmişlerdir. Görüşmeler, katılımcıların tercihi ile kendi ev ortamlarında gerçekleştirilmiştir. Görüşme öncesi katılımcılara çalışmanın amacı hakkında bilgi verilmiş ve ses kaydı yapma konusunda izinleri alınmıştır. Kayda geçirilen veriler görüşme sonrasında araştırmacı tarafından yazıya dökülmüş, bir diğer uzman tarafından kontrolleri sağlanmıştır. Toplanan nitel veriler, betimsel ve sistematik analizle değerlendirilmiştir.

\section{BULGULAR}

Annelerin Yas Sürecine İlişkin Bulgular

Annelerle yapılan görüşmeler, annelerin, çocuklarının engelli olduğunu öğrendikleri andan itibaren zaman içinde içsel ve davranışsal aşamalardan geçtiğini göstermiştir.

\section{Aşama: Şok ve İnkar}

“Çok çok büyük bir şok yaşıyorsunuz. Anlatılacak bir şey değil. Hiç beklemediğim bir şey. (Aydan)

Tuba Hanım test sonucunu öğrendiği an bunun bir şaka ya da kötü bir rüya olduğunu düşündüğünü şu sözlerle aktamıştır:

"Doktor aradı beni ve çocuğunuz engelli dedi. İlk tepkim "şaka..." oldu. Şaka dedim bu şaka. Bir yerlerde kerahat vaktinde uyudum herhalde kabus görüyorum. Eşime söyledim, o sırada arabadaydık, arabayı durdurdu ă̆lamaya başladi..."(Tuba)

Down Sendromlu bir erkek çocuğuna sahip olan Saliha Hanım, gerçekle ilk yüzleştiğinde, nasıl o gerçeği inkar etmeye çalıştığını şöyle ifade etmiştir; 
"Doktor bu ihtimalden bahsettiğinde, hayır dedim, kesinlikle bir hata var ve ben bu hatayı ortaya çıkaracağım. Dünyada ne kadar doktor varsa hepsine göstermem de gerekse çocŭ̆umda öyle bir şey olmadığını göstereceğim"(Saliha)

Inkar, benlik için tehlikeli görülen bir gerçekten korunmak için organizmanın kullandığ Durumun gerçekliğini idrak etmek için birey inkar aşamasında kendine biraz zaman tanımış olarak düşünülebilir ancak bu aşamanın sonlanmadığı durumlarda, aile içinde çözüme yönelik adımların atılmasını engelleyen büyük bir sorun haline gelebilmektedir.

"Çocuğumuzun durumu hakkında hiçbirşey bilmiyorduk araştırma yapmamız gerektiğini düşündüm. Onun için ne yapabilirdik bilmiyordum ama harekete geçmemiz lazımdı. Ben böyle düşünürken eşim hala konu hakkında konuşmayı reddediyor ve böyle bir sorunumuz yokmuş gibi davranıyordu. O süreçte beni en çok zorlayan onun bu inkar eden haliydi.(Zehra)

Down Sendromlu bir kız çocuğu olan Küçükkurutlư²0, o dönemdeki duygularını şu şekilde aktarmaktadır:

"Down Sendromunu çocuğum bir aylıkken sarllığı geçmediği için götürdüğ̈̈m doktor belirtileri var dediğinde galiba dedim hiç olmayacak birşeyden bahsediyor..."

$\mathrm{Bu}$ süreçte annelerin, insanların genel olarak sahip olduğu "gerçekçi olmayan iyimserlik" düşüncesine sahip olmaları nedeniyle büyük bir şaşkınlık ve kabullenememe yaşadıklarını söylemek mümkündür. Insanlar dünyanın güvenli ve anlamlı bir yer olduğunu varsayma eğilimindedir ${ }^{21}$. Bu nedenle varsayımlarımız arasında yer alan "Benim başıma gelmeyecek" ifadesinde de görebildiğimiz gerçekçi olmayan iyimserlik "incinmezlik yanılsaması" olarak da bilinmektedir22 23

20 Mustafa Küçükkurutlu, Facebook Anadolu Down Sendromu Derneği, 2014, Erişim Tarihi: 25. 05. 2016

https://www.facebook.com/groups/adsdtr/permalink/10152813972259866/

21 Neil D. Weinstein, "Unrealistic Optimism About Susceptibility to Health Problems: Conclusions from a Community-Wide Sample", Journal of Behavioural Medicine 10, 5 (1987), 481-498.

22 Linda S. Perloff, Social Comparison and Illusions of Invulnerability to Negative Life Events. In C.R. Snyder and C.E. Ford (Eds.), Coping with Negative Life Events: Clinical and Social Psychological Perspectives (New York: Plenum.1987), 217-242.

$$
\text { cumhuriget ilahigat dergisi 20, sy. 1 (Haziran 2016): 225-244. }
$$


Akkan (2014) ${ }^{24}$ ise, yaşadığg ilk şokun etkisini, satırlarına şu şekilde aktarmaktadır:

"Ateşi sık sık çıkıyor, hemen hastalanıyordu. "Biraz daha ateşi çıksın, belki ölür kurtuluruz" diyordum içimden, ama daha düşüncem netleşmeden içime ateş düşüyordu ve hemen doktora koşuyorduk."

Çocuğunun ölmesini istemek, gerçek bir şok, inkar ve kabullenememe sürecinin yansıması olarak karşımıza çıkmaktadır. Aydan Hanım'ın yaşadığı süreç de benzer tarzda yansımaktadır:

"Ve bu reddetme döneminde ben 4-5 ay her gün değil ama ara ara öl de kurtulayım dedim ona. Hep hastanelerdeydik hep hastalanıyordu ben de öl de kurtulayım dedim defalarca. Kabullenene kadar böyle sürdü." (Aydan)

Melike hanım, inançlarının Allahın takdirine rıza göstermek olduğunu, ancak ilk tepkilerinin şok ve inkar olduğunu, şu şekilde aktarmıştır:

"Allah'ın verdiği herşeye razı gelmek diye bizde kural vardır bizde. Ne olursa olsun Allah'ın verdiğinize razı geleceğiz diye öğrendik aynı şekilde ben de imtihan olarak gördüm. Ama ilk tepkim şok olmaktı, kesinlikle Kabul etmek istemedim. Hastaneyi ayağa kaldırdım kriz geçirdim ağlayarak. Sonra sessiz bir dört ay geçirdik. Test yaptırmamız gerektiğini biliyor ama erteliyorduk. Sonuçta internetten baktı eşim ve bunun bir tedavisi yoktu o zaman testi yaptırsak ne olacaktı. Şimdi düşünüyorum da ben o dönem kabullenememiştim henüz. Testi reddediyordum inkar ediyordum gerçeği. Sonra testi yaptırmak zorunda kaldık...." (Melike)

\section{Aşama: Öfke}

Hiç beklemedikleri böyle bir acı sürprizle karşılaşan annebabaların, ilk şoku atlattıktan sonra duyduğu belirgin bir duygu olarak karşımıza yalnızlık, çaresizlik ve öfke çıkmaktadır. Annelerin öfke

23 Linda S. Perloff ve Barbara K. Fetzer, "Self-Other Judgements and Perceived Vulnerability to Victimization", Journal of Personality and Social Psychology 50, 3 (1986), 502-510.

24 Nermin Akkan, Facebook Kişisel Sayfas1, 2014, Erişim Tarihi: 26.05.2016 https://www.facebook.com/nermin.akkan/posts/695254017228334:4 cumhuriget theology journal 20, no. 1 ( June 2016): 225-244. 
evresinde, kendilerini, eşlerini, aileyi, uzmanları ve Tanrıyı suçlamaları ve bu öfkeyi bu sayılanlardan birine, birkaçına ya da tamamına tekrarlarla yönelttikleri görülmüştür. Aileye ve eşe duyulan öfkede yalnızlık ve desteksiz bırakılma duyguları öne çıkmaktadır:

"Olayın sebebini sorgulayıp her defasında başka bir suçlu buluyordum. Herkes arayıp sabret sevabı büyük diyordu. Bir Allah'ın kulu da gerçekten yanımda değildi ya da ben o an böyle hissediyorum. Koca dünyada ben ve bebek kalmıştık sanki. Ona bakıp bakıp ağlıyordum." (Saliha)

Akkan(2014) da, satırlarında, araştrımanın sonuçlarını destekler nitelikte ifadelere yer vermektedir:

"Ankara soğuk, Ankara ıssız, Ankara taş blok. Eş yok, dost yok, kucaklarında bir yaratık ve iki çaresiz insan. Sihhıye'ye kadar hiç konuşmadan yürüdük. Sadece el eleydik. Ben yine hiç konuşmadan otobüse bindim evin yolunu tuttum. Eve nasıl geldim, kızımı kim aldı kucă̆ımdan, kiminle ne konuştum hatırlamıyorum. Bir öfke krizi geçirdiğimi söylediler. Annem, babam, kız kardeşim ve iki oğlum korkuyla izlemişler beni. Kırılabilecek ne varsa kırmışım. Eşim eve geldiğinde sessiz sessiz, yarı uyur, yarı uyanı ağlıyordum. Yanıma geldi, başucuma oturdu, saçlarımı okşamaya başladı. Yüzüme damlayan gözyaşlarını fark ettiğimde boynuna atıldım..." (Akkan)

Eşlerin sorunun nedenleri konusunda birbirlerini mantıklı ve mantıksız gerekçelerle suçladıkları görülmektedir:

"Çocuğumuz Down Sendromlu doğunca eşim bunun sebebini bana yordu. "doğru dürüst namaz kılmayı bilmiyorsun olacağı buydu" demişti. Ama kendisi de bilmiyor aslinda. Senin annen baban benim annem babam hep namaz kiliyordu. O zaman onlarm hürmetine vermezdi Allah! Bunu bilemezsin ki? Belki benim namazımın mükafatı ahirette verilecek, belki Allah katında kıymeti çok ayrı? Bunu bilemez ki. Kul kulu yargilayamaz bence..." (Aydan)

Hayat akışının hiç beklenmedik bir anda ve daimi olarak değiştiği böyle durumlarda, insanların çevrelerinden desteğe ihtiyaç duyması ve zaman zaman mantıklı veya mantıksız beklentiler içine girmesi son derece beklendik ve sık karşılaşılan duygular olarak karşımıza çıkmaktadır. $\mathrm{Bu}$ yalnızlık ve öfke duygularına, zaman zaman suçluluk ve cezalandırılmışlık duyguları da eşlik etmektedir.

cumhuriget ilahigat dergisi 20, sy. 1 (Haziran 2016): 225-244. 
Engelli Çocuğa Sahip Annelerde Yas Süreci I 237

"Yüreğim yaralı acılar içinde savaşıyordum, çok yalnızdım, kimseyi görmek ve dinlemek istemiyordum, acılarımı kendi içimde yaşamaya başlamıştım. İnsanların acıdığını düşünüyordum, bu yaşadıklarım hikaye değildi gerçek yaşamın bir parçasıydı. İ̧imi suçluluk duygusu sarmıştı bedenimi beynimi, hiç bir şey düşünemez olmuştum sadece aklımdaki neden ben? Neden ben?"25

Çocuğun engel durumunu anne karnındayken tespit edemediği gerekçesiyle öfkesini doktora yönlendirmek de, bu aşamanın yaygin tutumlarından biri olarak karşımıza çıkmaktadır:

"Eşim doktora dava açmak konusunda çok ısrarliydı. Doktorun ben hamileyken bunu farkedememiş olmasını kabul edemiyordu. Iyi de fark etse ne olacaktt? Çocuk karnımda büyümüş, kocaman olmuş, öldürecek miydik biz onu o zaman? Bunu düşünmüyordu. Sadece hatalı bir durum vardı o an bizim için ortada, ve her hatanin da bir sorumlusu olmalıdı! (Zehra)"

\section{Așama: Pazarlık}

Pazarlık aşaması, anne babaların inkar edilemez bir durum olduğunu gördükten sonra durumun seyrini değiştirmenin mümkün olabileceğine dair ümit ve çabaların yer aldığı evredir. Bu evrede annelerin, metafizik ögelerden de yardım alamya çabaladığı, bir mucize beklentisi içinde olduğu görülmektedir. Eğer çok çabalar daha çok doktora götürürsek iyileşir mi? eğer günahlarımıza tevbe eder iyi birer kul olursak Allah çocuğumuzu iyileştirir mi? gibi düşüncelerden kaynaklanan çabalar bu evrede kendini göstermektedir. Melike hanım, şok ve inkar aşamasından sonra, test yaptırmayı kabul ederken, testin sonucunun beklendiği 2-5 ayın onun için en stresli dönem oluduğunu ifade etmiştir. Bu dönemde, aşama yaklaşımının tipik pazarlık aşamasını net şekilde görmek mümkündür:

"Sonuç çıkmadan önce ben adak adadım. Ĕ̆ger testte çocuğum sağlıklı çıkarsa bütün dü̆g̈ünde takılan altınlarımı dağıtacă̆ım dedim. Testte Down Sendromu çıkınca yaptığım pazarlıktan utandım. Tamamını olmasa da altınların

25 Saniye Rodoplu, Facebook İzmir Down Sendromu Derneği Sayfası, 2015. https://www.facebook.com/IzmirDownSendromuDernegi/photos/a.1374693289521863.1073741828.13 74675669523625/1479279275729930/?type=3\&theater Erişim Tarihi: 26.05 .2016

$$
\text { cumhuriget theology journal 20, no. 1 (June 2016): 225-244. }
$$


bir kısmını çocuğum bundan sonra sağlıklı olsun kazadan beladan korunsun diye dağıttım."

Pazarlık aşaması, annelerin, gerçeği kabul etmek istemeyip bir mucize beklentisiyle Allah'a yöneldikleri, adaklar adayıp, iyi bir kul olmak için sözler verdikleri, türbelere giderek dualar ettikleri dönem olarak karşımıza çıkmaktadır.

\section{Aşama: Depresyon}

Engelli bir çocuğa sahip olma gerçeği yüzyüze kalan annelerin, inkar, öfke ve pazarlık aşamalarından sonra, bu gerçeğin değişmeyeceğini farketmeleri, onları çaresizlik ve derin bir üzüntü içine sokmaktadır. Bu dönem, annelerin, mücadeleden vazgeçip kederlerini yaşadıkları, kendilerini yalnız ve çaresiz hissettikleri, sosyal ortamlardan uzaklaştıkları ve çok sık ağladıkları bir süreci kapsamaktadır.

"Önce kabul etmek istememiştim, doktorun yanlışı olmalıydı, başka doktorlara gösterdik. Sonuç değişmiyordu. içimde binlerce soru vardı, neden bana verdi Allah bu çocuğu? Beni hamileliğimde yalnız bırakan eşime, birtakım sıkıntılar yaşamama sebep olan aileme, să̆liklı hamilelik geçirmeme engel oldukları için çok kızdım o dönemde. Sorumlusu kimdi bu durumun bilmiyordum ama herkese öfkeliydim. O kadar çaresizdim ki elimden sadece ă̆lamak geliyordu. Kimseyi görmek istemiyordum. Sadece bebeğime sarılıp ă̆lıyordum...(Zehra)"

\section{Aşama: Kabullenme}

Annelerin sürece adaptasyonu her zaman aynı süre içinde gerçekleşmemekte ve "kabullenme" süreci oldukça uzun sürebilmekte, bu süreç düşüncelerin farklı mecralara akabildiği dönemler olarak yaşanabilmektedir. Tuba hanımın şu ifadeleri, aslında bu sürecin bir özeti gibidir.

"Hemen kalp doktoruna gittik. Kalbi delik ölebilir dedi. Ölse mi acaba diyorsun o zaman... Ama çok tatlı, sevgisi var. Öyle bir süslemişim ki kızımı... Dedim ki bunun geri dönüşüm kutusu yok atalım yenisi gelsin... Yok böyle birşey. Bunu kabul edeceğiz..."

$\mathrm{Bu}$ şekilde başlayan kabullenme süreci, zamanla anlam bulma çabasına dönüşmektedir.

$$
\text { cumhuriget ilahigat dergisi 20, sy. 1 (Haziran 2016): 225-244. }
$$


Engelli Çocuğa Sahip Annelerde Yas Süreci I 239

"Gerçeklerle yaşamak, bu acı dolu günleri geride bırakmak biraz zaman aldl, ayakta durabilmem için gerçekleri kabul edip hayatta güçlü olmalıydım(...)Tanı ne olursa olsun tek bir gerçek vardı çocuğumun durumunu gözardı edemezdim, bir an önce kendimi toparlamalıydım, herşeye rağmen benim dünya tatlısı, nur topu ve kocaman gözleriyle ışıl ışıl bana bakan bir oğlum vardl. Ama duygularım hala karmakarışıktı, daha önce yaşadığım firtına biraz durulmuştu. Çocuğumun durumunu soranlara tekrar tekrar açıklamak bana çok act veriyordu.."(Rodoplu,2013)

Yas sürecinin son aşamasında, annelerin, kabullenme ile birlikte hayata daha anlamlı bakabildiklerini, çocukları için hayatlarını yeni bir çerçeveye oturttukları görülmüştür:

“...Kızımdan sonra dert ettiğgim şeylerim azaldı. Bir olgunluk geldi. Ve bana özgüven geldi. Şimdi daha güçlü olduğumu hissediyorum. Daha önce veremediğim kararları şimdi çok güzel veriyorum sinırlarımı rahat koyuyorum. Ben güçlüyüm, güçlü durmalıyım, kızım için de daha güçlü olacağım, daha aktif olacağım diyorum. Hem kendime bakmam lazım, hem kızımı süslemem ve ona güzel bakmam lazım. Kızım sayesinde hayatım ayıklandı. Ve ayıklanınca daha mutlu oldum. Mutlu olduğum kişilerle görüşüyorrum. Elbette çok çok dirençliyim kuvvetliyim diyemem. Ama hayat zaten bir şekilde çektirir. Eşinden ya da sağlıklı çocupun ya da maddiyat ya da ailen, biri çektirir. Ben merkeze kızımı koymadım. Hayat dev bir puzzle ve biz birleştiriyoruz yaşadıkça..." (Tuba)

"Biz ve çevremizdeki birçok insan, oğlum sayesinde, hayata bambaşka açılardan, çok daha ayrıntılı bir şekilde bakma fırsatını yakaladık. Rabbim gözden kaçırdıklarımızı bize hatırlatsın ve tüm insanlara farklilıklara doğru açıdan bakabilmeyi nasip etsin ki onlar da daha güzel bir hayat sürebilsin. Artık dualarımda sadece kendi çocuğum değil, tüm engelli çocuklar için dua ediyorum. Bu durum insana inanılmaz bir huzur veriyor. Hiç tanımadığınız insanları yıllardır tanıyormuşsunuz en yakınlarınızmış gibi hissediyorsunuz. Evet hamd olsun şimdilerde daha kolay her şey."(Muazzez)

\section{SONUÇ}

Öncelikle vurgulanması gereken önemli bir husus, yas tepkilerinin kişiye özgü olduğudur. Bu nedenle, engelli çocuğa sahip annelerin yaşadığ 1 sürecin de biricik olduğunun bilinmesi gerekir. Bununla beraber, engelli bir çocuğu kucaklarına aldıklarında ideallerindeki çocuğun 
kaybını yaşayan annne babalardan bazıları bu yası ömür boyu taşımaktadır. Yası tutulan kayıp, zihinlerde oluşturulan ideal çocuğun kaybıdır. Hayatın en anlamlı projesinin kaybıdır. Evet, her anne hayalinde ideal bir bebek büyütür. Ama kucaklarına verilen, beklediklerinin çok dışında biridir. Bu durum, annelerin zaman zaman, ideal bebeğin kaybından doğan, derin bir keder ve yas yaşamalarına neden olabilmektedir. Bebeğin yaşamına katılmasını takip eden ilk dönemde özellikle yaşanan kabullenememe süreci (inkar aşaması) bir yönüyle de aslında annelerin, bekledikleri bebeğin kaybının yasını tuttuğu bir dönemdir.

$\mathrm{Bu}$ süreçte anne-babanın yaşama olan güveninde bir sarsılma olabilmektedir. Her bireyin yaşama güvenle bakabilmesi için ihtiyaç duyduğu bir inançtan bahseder Weinstein, olumsuz şeylerin başımıza gelmesine, bu olumsuzlukların başkalarının başına gelmesinden daha az ihtimal verdiğimiz gibi, olumlu şeylerin başımıza gelmesine de ortalamanın üstünde ihitmal verdiğimizi belirtmektedir. Bu, "incinmezlik yanılsaması", "benim başıma gelmez" düşüncesinde ifadesini bulmaktadır. Evet, dile getirsek de getirmesek de hepimiz zaman zaman, kötü şeylerin bize değil, başkalarına olacağına inanırız. Ama başına kötü şeyler gelenler de aslında bizim gibi insanlardır. İşte beklenmedik ve istenmedik bu durumla birdenbire karşı karşıya kalan annelerde, yaşama yönelik geliştirdikleri güvende olma duygusu sarsılır. ${ }^{26}$

Bu başlarına gelen,"neden onların başına gelmiştir?" incinmezliğe olan inancın sarsılması, durumun "aslında öyle olmadığı", " kesinlikle bir hata olduğu" ve "biz bunu değiştiririz" düşünceleriyle geçici olarak güç bulmaya çalışır. Anneler, bebeğin engelli olup olmadığı hakkında bir takım fiziksel belirtilere dayanarak fikir yürüten doktorların yanılmış

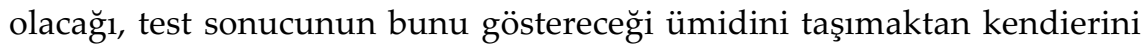
alamazlar. Test sonucunun beklendiği süreç, böyle korku-ümit arası gelgitlerin yaşandığı zorlu bir dönemdir. Bu dönem literatürdeki "pazarlık" aşamasının en yoğun göründüğü zaman dilimidir. Anneler, babalar ve aile büyükleri, bir tür dini başaçıkma tarzına sarılırlar. Adak adamak, hocaya okutmak, türbeleri ziyaret etmek ve dua halkaları kurarak, sonucun sevindirici olması için "ellerinden geleni yapmış olmak" isterler.

26 A. Burcu Gören, "Down Sendromlu Bireylerin Manevi Bakım İhtiyactnın Belirlenmesi ve Bir Model Önerisi" (Doktora Tezi, Ankara Üniversitesi, 2015). cumhuriget ilahigat dergisi 20, sy. 1 (Haziran 2016): 225-244. 
Öfke aşamasında annelerin, ihtiyaç duydukları sosyal desteği göremediklerini hissederek, kendilerini yalnız bırakan aile fertlerine, arkadaş gruplarına karşı kırgınlık ve öfke besledikleri görülmektedir. Ayrıca gebelik sürecinde kendilerini engelli bebek konusunda bilgilendirmediği için doktora ve durumu doğumdan sonra kendilerine açıklarken doğru üslup kullanılmadığı gerekçesiyle doktora ya da ilgili sağllk personeline, hatta doğumun gerçekleştiği hastane binasına dahi öfke duydukları görülmüştür. Bunun yanısıra, geçmiş hatalarını anımsayarak kendine ya da gebelik sürecindeki hataları ya da ihmali gibi gerekçelerle eşe de öfke duyulabilmektedir. Bu bekleyişle geçen zaman diliminde, anneler bazı içsel süreçlerden geçmektedir. Bu "kötü durum" neden onların başına gelmiştir? Bu sorunun cevabını bulabilseler, herşeyi kabul etmenin çok daha kolay olacağını düşünürler. Evet, bu yaşananların bir anlamı olmalıdır. Çünkü insan, eğer bir anlamı varsa, neredeyse her acıya göğüs gerebilirken, eğer bir anlamı yoksa, küçük acılara karşı bile tahammülsüz olmaktadır. Ve insanın anlam arayışı, yaşamın böyle zorlu dönemlerinde kendini daha çok göstermektedir. Anlam arayışları anne ve babaları, ilahi adalet inanciyla, "acaba bir hatamız mı oldu?" "birinin ahını mı aldım?" "eski nişanlım mı acaba..." "annem öyle beddua etmeseydi keşke..." gibi soru ve sorgulamalara götürür. Eşler, bu duygu ve düşüncelerle, aynı soruları hem kendilerine hem de birbirlerine sorabilirler. Bu tür başaçıkma yöntemleri, kişiyi geçici olarak anlam bulma duygusuna ulaştırsa da, devamında olumsuz duygu ve düşüncelerin artmasına ve durumla barışamamaya neden olur. Görüşmelerden ulaşılan sonuç, bu tür bir başaçıkma yöntemine, bebeğin doğumunu izleyen ilk aylarda daha yoğun şekilde başvurulduğudur. Bu aşama, öfke duygusunun kendine yöneltilmesiyle suçluluk duygusunun ortaya çıkmasıdır. İlerleyen dönemlerde anne-babalar, engelli çocuğun bazı hata ve günahlarının neticesi -cezası- olarak kendilerine verilmiş olabileceği düşüncesinin mantıksızlığına ve ne kendilerine ne de çocuklarına ve sürece uyumlarına bir faydasının olmadığını farkederler. Ama ilk dönem için, geçici bir anlam verme sağlayan ve geçici de olsa faydalı kabul edilebilen "ilahi adalet inancı", dışarıdan kişilerin yorumlarında yer aldığında ise, son derece yıkıcı etkiye sebep olabilir. Suçluluk duyguları, aynı düşünceler kendisinin aklından geçse bile, bir başkasından duyulduğunda, öfke, mutsuzluk ve savunma gibi tepkilere yol açabilmektedir. 
İlk üç aşama, şu sonuçlarla tamamlanmaktadır:

İnkar aşamasının sonunda; Çocuğun engelli olduğu inkar edilemez bir gerçektir

Öfke aşamasının sonunda; Suçlu aramak, kendini ya da başkalarını suçlamak ya da kadere isyan etmek, gerçeği değiştirmeyeceği anlaşılmıştır

Pazarlık aşamasının sonunda; Bu gerçeğin rasyonel ve irrasyonel hiçbir çabayla değişmeyeceği anlaşılmıştır.

Anneler varılan bu sonuçlardan sonra, çaresizlik hissederler. Gerçek değişmez biçimde önlerindedir, mutsuzluk en yoğun biçimde bu dönemde hissedilir. Hayatın günlük akışından uzaklaşılır. Sosyal çevreyle ilişkiler kesilir. Depresyon evresinde, anne, hüzünlü ve acı doludur. Elbette her evrede olduğu depresyon aşaması da her annede aynı şiddet ve etkide kendini göstermez. Anneler bu evreyi, sosyal destek, inanç sistemi gibi içsel ve dışşal güç kaynaklarıyla, anlam mekanizmalarıyla ve kullandıkları başaçıkma stilleriyle atlatabilmekte ya da uzman desteğine ihtiyaç duymaktadırlar.

Yasın son aşaması olan kabullenme aşamasında engelli çocuğa sahip anneler gerçeğin kabulü ile beraber "durum bu, öyleyse bundan sonra ne yapabiliriz?" sorusunu sormaktadır. Çocuklarının kapasitelerini en iyi şekilde değerlendirme, onları topluma kazandırma, kendi yaşamlarını bu yeni şartlara uygun şekilde yeniden biçimlendirme, kısacası hayatı yeni bir çerçeveye koyma çabası içine girerler. annelerin bu aşamaya geçişinde en önemli güç kaynakları çocuklarına duydukları büyük sevgi ve şefkat olmaktadır ${ }^{27}$. Yaşamın yeniden biçimlendirildiği bu dönemde annelerin karşılaştığı en önemli sorun, yas tepkilerinin ve içinde bulunulan aşamanın eşler arasında bir senkronizasyonla yaşanamıyor oluşudur (Göka, 2009). Eşlerin yas tepkilerinin farklı olması aile içinde iletişimsizlik gibi, sorunların çözümüne yönelik adımlar atılamaması gibi, aile içi sorunlar ve parçalanmalara yol açabilmektedir.

27 Mary Beth Goring, "The Cycle of Love and Grief in Parents of Children with Special Needs" AG Bell's Listening and Spoken Language Symposium (2013)

$$
\text { cumhuriget ilahigat dergisi 20, sy. 1 (Haziran 2016): 225-244. }
$$


Konuyla ilgili şu önerilerde bulunulabilir:

Engelli çocuğa sahip annelerin her evrede desteğe ve özene ihtiyacı vardır. Bu gereklilik şu aşamaları içermektedir:

1. Çocuğun engelli olduğu haberinin anneye profesyonel ve insani bir yaklaşımla verilmesi, annenin yas tepkileri üzerinde son derece etkilidir.

2. Annenin aldığ 1 bu haberle beraber bir sürece girdiği ve yas sürecinin yaşanması gerektiği konusunda aile bireylerinin bilinçlendirilmesi gerekmektedir.

3. Engelli çocuğa sahip annelere yas sürecinin sağlıklı atlatılması için psikolojik destek verilen yas danışmanlığı konusunda uzmanların rol aldığı bir sisteme ihtiyaç vardır.

\section{KAYNAKÇA}

Akkan, Nermin. Facebook Kişisel Sayfas1, 2014, Erişim Tarihi: 26.05.2016 https://www.facebook.com/nermin.akkan/posts/695254017228334:4

Darıca, Nilüfer, Ülkü Abidinoğlu ve Şebnem Gümüşçü. Otizm ve Otistik Çocuklar. İstanbul: Özgür Yayınları, 2000.

Genlik, Özge. "Yas Süreci ve Yas Sürecindeki Kişilerin Depresyon ve Anksiyete Düzeylerinin Incelenmesi". Yüksek Lisans Tezi, Arel Üniversitesi, 2012.

Gizir, Cem Ali. “Bir Kayıp Sonrasında Zorluklar Yaşayan Üniversite Öğrencilerine Yönelik Bir Yas Danışmanlığı Modeli". Mersin Üniversitesi Ĕ̆gitim Fakültesi Dergisi 2, 2 (2006).

Goring, Mary Beth. "The Cycle of Love and Grief in Parents of Children with Special Needs" AG Bell's Listening and Spoken Language Symposium, 2013.

Göka, Erol. Hoşçakal. İstanbul: Timaş Yayınları, 2009.

Gören, A. Burcu. "Down Sendromlu Bireylerin Manevi Bakım İhtiyactnın Belirlenmesi Ve Bir Model Önerisi". Doktora Tezi, Ankara Üniversitesi, 2015.

Humphrey, Karen M. Counseling Strategies For Loss And Grief. Alexandria, VA: American Counseling Association, 2009.

Iş11, Özlem, Semra, Karaca. “Ölüm Yaklaşırken Yaşananlar ve Söylenebilecekler: Bir Gözden Geçirme”. Maltepe Üniversitesi Hemşirelik Bilim ve Sanatı Dergisi, 2009. İçmeli, Celalettin, Ahmet Ataoğlu, Fatih Canan ve Adnan Özçetin. "Zihinsel Özürlü Çocukları Olan Ebeveynler ile Sağlıklı Çocuklara Sahip Ebeveynlerin Çocuk Yetiştirme Tutumlarının Karşılaştırılması". Düzce Tıp Fakültesi Dergisi, 3 (2008), 21-28.

$$
\text { cumhuriget theology journal 20, no. 1 (June 2016): 225-244. }
$$




\section{4 | Ayşe Burcu Gören}

Kübler-Ross, Elisabeth. Ölüm ve Ölmek Üzerine. İstanbul: Boyner Holding Yayınları, 1997.

Küçükkurutlu, Mustafa. Facebook Down Sendromu Sayfas1, 2014. Facebook Anadolu Down Sendromu Derneği, 2014. Erişim Tarihi: 25.05.2016 https://www.facebook.com/groups/adsdtr/permalink/10152813972259866/

Mestçioğlu, Ayşe Özlem ve Ebru Sorgun. Travmatik Yas. İçinde Aker T. ve Önder M.E. (Edt), Psikolojik Travma ve Sonuçları. İstanbul: 5US Yayınları Epsilon Reklamcilık, 2003.

Smith, Robert M. ve John T. Neisworth. The Exceptional Child: A Functional Approach. New York: McGraw-Hill, 1975.

Moses, Ken. The Impact of Childhood Disability: The Parent's Struggle. WAYS Magazine, Spring. Evanston, IL, 1987.

Olsson, MB. "Parents of Children with Intellectual Disabilities". Goteborgs Universitet, Unpublished Doctorate Thesis, Sweden, 2004.

Perloff, Linda S. "Social Comparison and Illusions of Invulnerability to Negative Life Events. In C.R. Snyder and C.E. Ford (Eds.), Coping with Negative Life Events: Clinical and Social Psychological Perspectives" New York: Plenum, 1987.

Perloff, Linda S. ve Barbara K. Fetzer. “Self-Other Judgements and Perceived Vulnerability to Victimization". Journal of Personality and Social Psychology 50, 3 (1986).

Rodoplu, Saniye. Facebook İzmir Down Sendromu Derneği Sayfası, 2015. https://www.facebook.com/IzmirDownSendromuDernegi/photos/a.137469328 9521863.1073741828.1374675669523625/1479279275729930/?type=3\&theater Erişim Tarihi: 26.05.2016

Weinstein, Neil D. “Unrealistic Optimism About Susceptibility to Health Problems: Conclusions from a Community-Wide Sample". Journal of Behavioural Medicine 10, 5 (1987).

Uğuz, Şükrü, Fevziye Toros, Banu Yazgan İnanç ve Oğuzhan Çolakkadığlu. "Zihinsel ve/veya Bedensel Engelli Çocukların Annelerinin Anksiyete, Depresyon Ve Stres Düzeylerinin Belirlenmesi". Klinik Psikiyatri 7, 2004.

Varol, Nihal. Aile Eğitimi. Ankara: Kök Yayıncılık, 2005.

Whiting, Mark. "What İt Means To Be The Parent Of a Child With a Disability Or Complex Health Need". Nursing Children and Young People 26, 5 (2014).

Worden, William. Grief Counseling and Grief Therapy: A Handbook For the Mental Health Practitioner Springer Publishing Company, 2001.

Yalom, Irvin D. Aşkın Celladı ve Diğer Psikoterapi Öyküleri. İstanbul: Remzi Kitabevi, 2000.

Zara, Ayten. Kayıplar, Yas Tepkileri ve Yas Süreci, Yaşadıkça: Psikolojik Sorunlar ve Başa Çıkma Yolları (Edt). İstanbul: İmge Yayınları, 2011.

cumhuriget ilahigat dergisi 20, sy. 1 (Haziran 2016): 225-244. 